\title{
Desain Sistem Biodiesel Berbasis PLC Berdasarkan Diagram Keadaan
}

\author{
Riky Dwi Puriyanto', Son Ali Akbar', Agus Aktawan ${ }^{3}$ \\ 1,2Program Studi Teknik Elektro, Universitas Ahmad Dahlan \\ ${ }^{3}$ Program Studi Teknik Kimia, Universitas Ahmad Dahlan \\ 1,2,3 Kampus IV, Jalan Ring Road Selatan, Yogyakarta, Indonesia 55166 \\ e-mail: ${ }^{1}$ rikydp@ee.uad.ac.id, ${ }^{2}$ sonali@ee.uad.ac.id, ${ }^{3}$ agus.aktawan@che.uad.ac.id
}

\begin{abstract}
Biodiesel is one type of biomass as a renewable energy resource. Biodiesel system is a sequential system that can be controlled with a programmable logic controller (PLC) device. Sequential system problems can be solved by making a state diagram that represents the conditions and transitions of the system. Biodiesel system is represented in a state diagram then converted into a ladder diagram as one of the programming languages of a PLC. The method of converting state diagrams into ladder diagrams is structured programming method used by both levels, beginners and experts in running PLCs. The advantage of this method is reliability in detecting errors in the process. The error can be known clearly and structured by programmers. The design of the human-machine interface (HMI) of the biodiesel system in this study was made on CX One software (CXP and CXD) using a PLC type CP1E. System design made based on a state diagram has been successfully tested. In this design, the required memory is $6.5 \%$ of the total memory of the PLC CP1E.
\end{abstract}

Keywords: Biodiesel; State diagram; Ladder diagram; PLC; CP1E; CX One

\begin{abstract}
Abstrak
Biodiesel merupakan salah satu jenis dari biomassa yang merupakan salah satu tipe sumber energi terbarukan. Sistem biodiesel merupakan sistem sekuensial (berurutan) yang dapat diatur dengan jenis pengendali programmable logic controller (PLC). Permasalahan sistem sekuensial dapat diselesaikan dengan membuat sebuah diagram keadaan (state diagram) yang merepresentasikan kondisi serta transisi yang ada pada sistem. Sistem biodiesel yang direpresentasikan dalam diagram keadaan kemudian dikonversi menjadi diagram ladder sebagai salah satu bahasa pemrograman sebuah PLC. Metode konversi diagram keadaan menjadi diagram ladder merupakan metode pemrograman terstruktur yang bermanfaat bagi programmer PLC baik level pemula hingga ahli dalam menjalankan PLC. Manfaatnya adalah kesalahan yang terjadi dapat diketahui dengan jelas dan terstruktur. Desain human machine interface (HMI) sistem biodiesel pada penelitian ini dibuat pada perangkat lunak CX One (CXP dan CXD) dengan menggunakan PLC tipe CP1E. Hasilnya adalah perancangan diagram keadaan sistem biodiesel dan konversi diagram keadaan menjadi diagram ladder telah berhasil dilakukan dengan baik. Pada desain ini memori yang diperlukan sebesar $6,5 \%$ dari total memori yang dimiliki PLC CP1E.
\end{abstract}

Kata Kunci: Biodiesel; State diagram; Diagram ladder; PLC; CP1E; CX One

\section{Pendahuluan}

Terdapat banyak sumber energi utama yang dapat dikelompokkan menjadi dua jenis, energi konvensional dan energi terbarukan. Sumber energi konvensional merupakan sumber energi yang didapat dari sumber yang jumlahnya terbatas di bumi dan tidak dapat diregenerasi. Sebaliknya, sumber energi terbarukan merupakan sumber energi yang berasal dari sumber alam dan dapat diregenerasi. Keuntungan penggunaan sumber energi terbarukan adalah mengurangi dampak buruk terhadap lingkungan yang saat ini menjadi salah satu topik utama yang dibahas di dunia. Salah satu bentuk sumber energi terbarukan adalah biomassa. Biomassa dapat diartikan sebagai material biologis yang berasal dari suatu kehidupan, atau organisme yang masih hidup yang memiliki struktur karbon dan di dalamnya terdapat bahan organik yang mengandung oksigen, hidrogen, nitrogen dan elemen lainnya. 
Biodiesel merupakan salah satu jenis biomassa. Biodiesel adalah bahan bakar alternatif diesel yang berasal dari bahan biologi melalui proses transesterification atau perubahan minyak nabati murni atau produk sampingan yang diolah menggunakan metanol dan katalis $\mathrm{NaOH}$. Salah satu minyak sayur yang digunakan adalah minyak goreng. Minyak goreng bekas adalah salah satu bahan baku yang memiliki peluang tinggi untuk pembuatan biodiesel karena masih mengandung trigliserida selain asam lemak bebas. Biodiesel dibuat dengan memberikan beberapa perlakuan fisik, seperti suhu dan durasi waktu pengendapan [1].

Biodiesel adalah bahan bakar ramah lingkungan. Biodiesel tidak mengandung kandungan berbahaya seperti $\mathrm{Pb}$, biodegradable, emisinya juga lebih rendah dari pada emisi bahan bakar diesel. Biodiesel memiliki efek pelumasan yang tinggi sehingga manfaatnya dapat memperpanjang umur mesin dan memiliki jumlah setana yang tinggi (> 50) [2]. Selain itu pemanfaatan bahan seperti minyak jelantah memberi dampak positif bagi lingkungan karena biasanya minyak jelantah sebagai produk yang dianggap sampah dapat dimanfaatkan untuk menghasilkan produk baru. Pemanfaatan minyak bekas ini juga dapat mengurangi biaya produksi biodiesel.

Secara umum sistem biodiesel tersusun dari beberapa proses seperti pada Gambar 1 [3]. Bahan minyak goreng/ jelantah dan katalis berupa metanol dan $\mathrm{KOH}$ dicampur dan dimasukkan ke dalam reaktor biodiesel untuk kemudian dicampur dan diolah menjadi biodiesel dan gliserin.

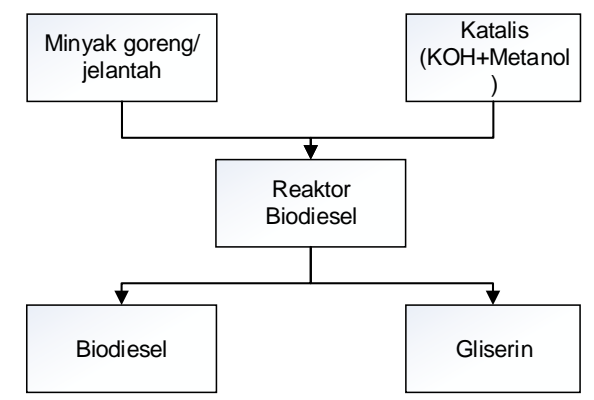

Gambar 1. Diagram blok sistem biodiesel

Sistem otomasi mengalami perkembangan yang pesat saat ini untuk mendukung optimasi dan kehandalan proses. Pekerjaan yang awalnya dikerjakan oleh manusia banyak yang beralih pada mesin untuk optimasi biaya yang ditanggung perusahaan. Para engineer berlombalomba memproduksi mesin dengan berbagai fungsi untuk mengoptimalkan pekerjaan pada perusahaan. Penggunaan mesin tersebut diharapkan memberi keunggulan berupa otomatisasi proses produksi yang dapat meningkatkan jumlah produksi serta meningkatkan efisiensi penggunaan bahan baku dengan memanfaatkan sensor-sensor untuk berbagai variabel.

Salah satu pengendali yang biasa digunakan dalam otomasi adalah PLC (Programmable Logic Controller). PLC merupakan suatu piranti elektronik yang dirancang untuk dapat beroperasi secara digital dengan menggunakan memori sebagai media penyimpan instruksi-instruksi internal untuk menjalankan proses, fungsi pewaktu, fungsi aritmatika, dan fungsi lainnya dengan cara memprogramnya [4]. PLC banyak digunakan dalam berbagai sistem pengendalian seperti conveyor dan motor induksi [5] [6]. Variabel input yang dapat diolah pada PLC seperti suhu, tekanan, aliran dan level ketinggian akan diproses di dalam PLC untuk menghasilkan keluaran berupa perintah berdasarkan program yang ada di dalam PLC. Secara garis besar hubungan masukan, keluaran dan program pada aplikasi PLC dapat dilihat pada Gambar 2 [7].

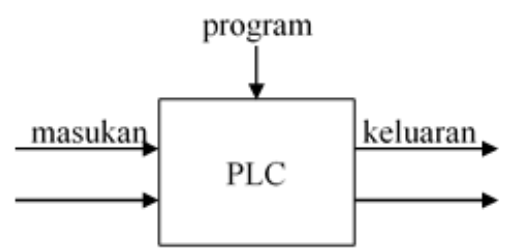

Gambar 2. Prinsip kerja PLC 
Beberapa penelitian penggunaan PLC pada sistem biodiesel fokus pada otomasi reaktor transesterifikasi biodiesel [3], pembuatan sistem pembilas/ pencuci otomatis [8], proses rektifikasi/ perbaikan etanol secara otomatis [9], dan lain sebagainya. Fokus penelitian ini adalah pemodelan sistem biodiesel berbasis PLC menggunakan bahasa ladder. Pada penelitian ini memberikan kontribusi:

1. Perancangan diagram keadaan (state diagram) yang menjelaskan sistem biodiesel;

2. Perancangan diagram ladder sistem biodiesel berbasis state diagram yang telah dibuat;

3. Pemodelan dan simulasi sistem biodiesel berbasis software CX Designer dengan PLC Omron tipe CP1E.

\section{Metode Penelitian}

Secara umum diagram alir penelitian ini tampak pada Gambar 3. Terdapat tiga tahapan: 1) perancangan siagram keadaan, 2) konversi diagram keadaan ke diagram ladder kemudian simulasi seluruh diagram ladder dan 3) perancangan human machine interface (HMI).

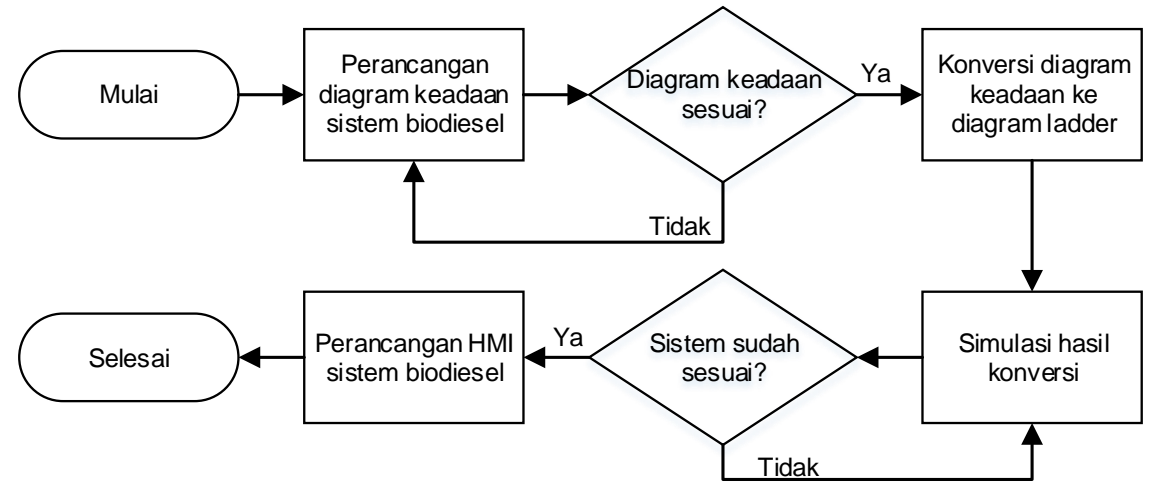

Gambar 3. Diagram alir penelitian

Diagram keadaan (state diagram) merupakan gambaran aliran proses sebuah sistem yang terdiri dari kondisi-kondisi yang dihubungkan oleh sebuah transisi berupak. Sebuah sistem besar tentu memiliki banyak kondisi yang mempengaruhi keluaran sistem. Gambar 3 menunjukkan diagram keadaan yang terdiri dari dua kondisi dan dipengaruhi oleh tiga logika transisi. Keadaan " $A$ " menghasilkan "Keluaran A" begitu juga keadaan "B" menghasilkan "Keluaran B". Pada transisi T0, T1 dan T2 masing-masing terjadi Logika 1, Logika 2 dan Logika 3 yang menentukan perpindahan keadaan dari Keadaan A ke keadaan B, begitu pula sebaliknya [10].
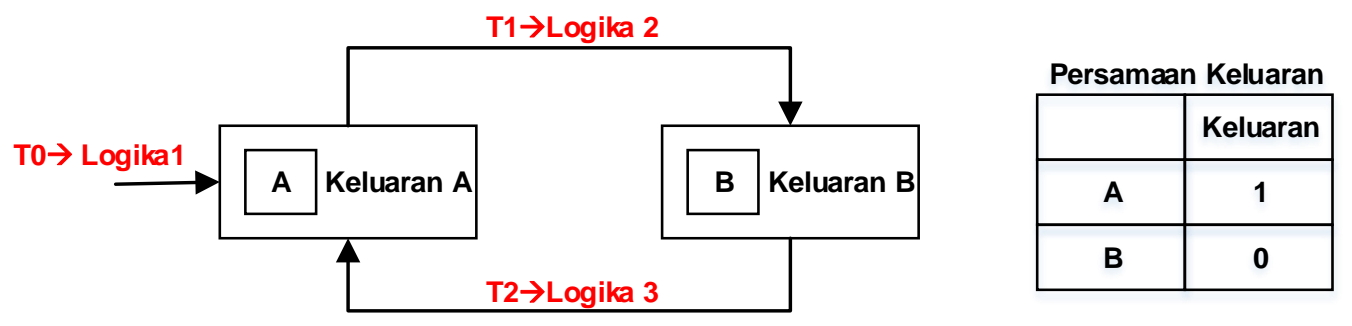

Gambar 4. Diagram keadaan

Diagram keadaan dapat digunakan untuk merepresentasikan sistem yang terdiri dari banyak masukan, keluaran dan kondisi. Penyusunan diagram keadaan dapat mempermudah perancang sistem dalam merancang program dan memperbaiki ketika ada kesalahan sistem. Diagram keadaan juga biasa disebut diagram fungsi sekuensial (sequential function chart) karena menunjukkan proses sistem secara sekuensial/ berurutan dari awal sampai akhir.

Konversi diagram keadaan ke diagram ladder dilakukan dengan melihat hubungan antara kondisi yang ada dengan transisi antar kondisi berupa logika-logika masukan. Blok kondisi saat ini dan kondisi sebelumnya merupakan variabel integer yang diatur untuk menggambarkan 
Jurnal IImu Teknik Elektro Komputer dan Informatika (JITEKI)

Vol. 4, No.2, Desember 2018

masing-masing kondisi. Skema tersebut harus dituliskan pada awal penyusunan diagram ladder. Secara umum penyusunan diagram ladder berdasarkan sebuah diagram keadaan (Gambar 4) dapat dilihat pada Gambar 5. Logika yang didapat dari Gambar 5 dapat dijelaskan sebagai kombinasi logika berikut ini:

$$
\begin{aligned}
& T 0=\text { Logika1 } \\
& T 1=\text { Logika2. Keadaan } A \\
& T 2=\text { Logika3. Keadaan } B \\
& \text { Keadaan } A=(T 0+T 2+\text { Keadaan } A) . \overline{T 1} \\
& \text { Keadaan } B=(T 1+T 2+\text { Keadaan } B) . \overline{T 2} \\
& \text { Keluaran }=\text { Keadaan } A
\end{aligned}
$$

Persamaan (1) sampai (3) menjelaskan transisi yang terjadi dalam sistem yang dibuat. Persamaan (4) dan (5) menjelaskan keadaan yang terjadi dalam sistem. Keadaan-keadaan yang terjadi akan mempengaruhi transisi yang ada. Sebuah keadaan akan berpindah ke keadaan lain akibat adanya logika-logika dari beberapa masukan yang mengakibatkan munculnya transisi. Keluaran yang dihasilkan dipengaruhi oleh keadaan yang ada pada sistem. Keluaran ini ditentukan oleh adanya tabel kebenaran untuk keluaran (Gambar 3).

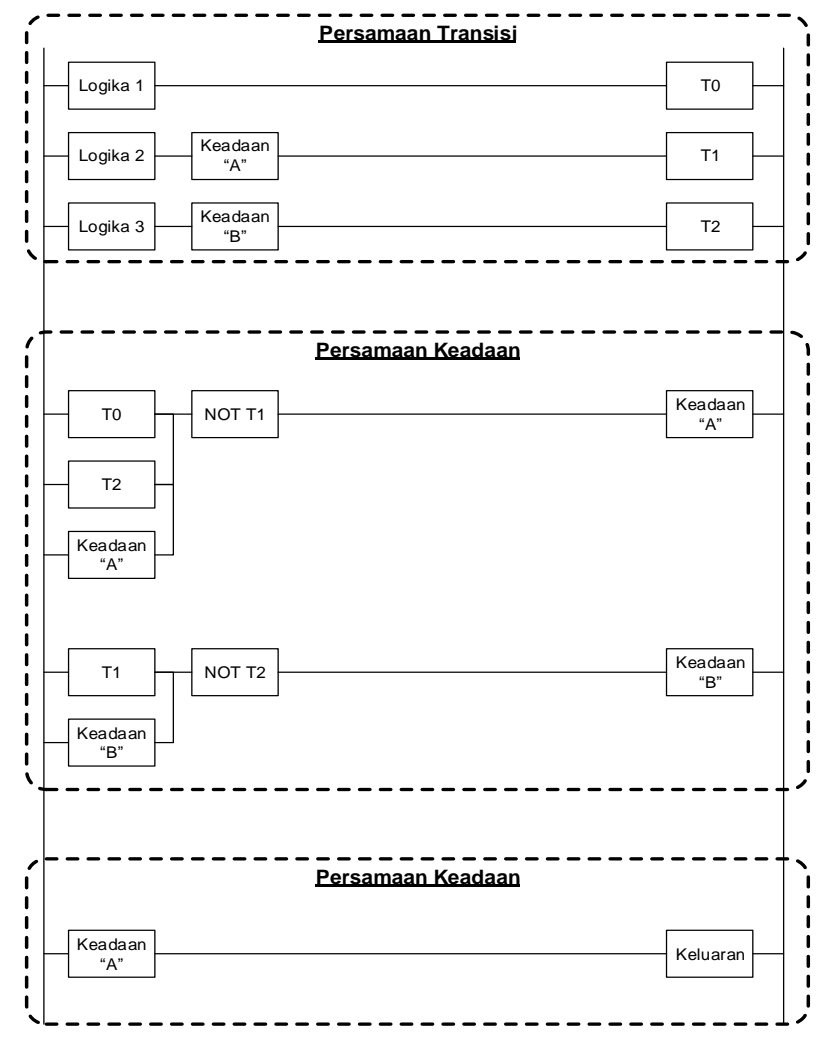

\section{Hasil dan Pembahasan}

Gambar 5. Rancangan diagram ladder

Sistem biodiesel dapat ditunjukkan dalam bentuk diagram keadaan seperti Gambar 6 . Sistem biodiesel merupakan sistem sekuensial yang dapat diselesaikan menggunakan pengendali PLC. Cara kerja sistem biodiesel Gambar 6 dapat dijelaskan sebagai berikut:

Kondisi 1-3: Sistem diawali dengan tombol "Sistem ON" yang ditekan untuk mengaktifkan seluruh sistem dengan ditandai lampu indikator sistem menyala.

- Kondisi 4: Valve 1-3 akan aktif ketika tombol "Mulai" ditekan, sehingga cairan dari tangki penyimpanan akan dialirkan pada ketiga tangki ukur yang dilengkapi sensor atas (SA1SA3) dan sensor bawah (SB1-SB3). 
Jurnal Ilmu Teknik Elektro Komputer dan Informatika (JITEKI)

Vol. 4, No.2, Desember 2018

- Kondisi 5: Ketika SA1 dan SB1 tangki 1 mendeteksi cairan maka valve 1 akan mati kemudian pemanas 1 dan pengaduk 1 akan aktif selama beberapa waktu (TIM1).

- Kondisi 6: Ketika SA2 dan SB2 tangki 2 aktif maka valve 2 akan mati dan valve 5 hidup untuk mengalirkan cairan ke tangki pencampuran 4.

- Kondisi 7: Ketika SA3 dan SB3 tangki 3 aktif maka valve 3 akan mati dan valve 6 hidup untuk mengalirkan cairan ke tangki pencampuran 4.

- Kondisi 8: Setelah cairan pada tangki 1 dipanaskan dan diaduk maka valve 4 akan aktif untuk mengalirkan cairan ke tangki pencampuran 5.

- Kondisi 9: Ketika SA4 dan SB4 mendeteksi cairan pada tangki pencampuran 4, cairan akan dipanaskan dan diaduk selama beberapa waktu (TIM2)

- Kondisi 10: Setelah cairan pada tangki pencampuran 4 dipanaskan dan diaduk, valve 7 akan aktif dan mengalirkan cairan ke tangki pencampuran 5 .

- Kondisi 11: Ketika SA5 dan SB5 pada tangki pencampuran 5 mendeteksi ada cairan, pemanas dan pengaduk akan aktif selama beberapa waktu (TIM3)

- Kondisi 12: Setelah cairan diaduk dan dipanaskan, valve 8 akan aktif untuk mengalirkan cairan ke bak penampung akhir biodiesel dan sistem akan kembali dimulai dari awal.

- Kondisi 13: Jika tombol "Berhenti" ditekan maka seluruh sistem akan mati

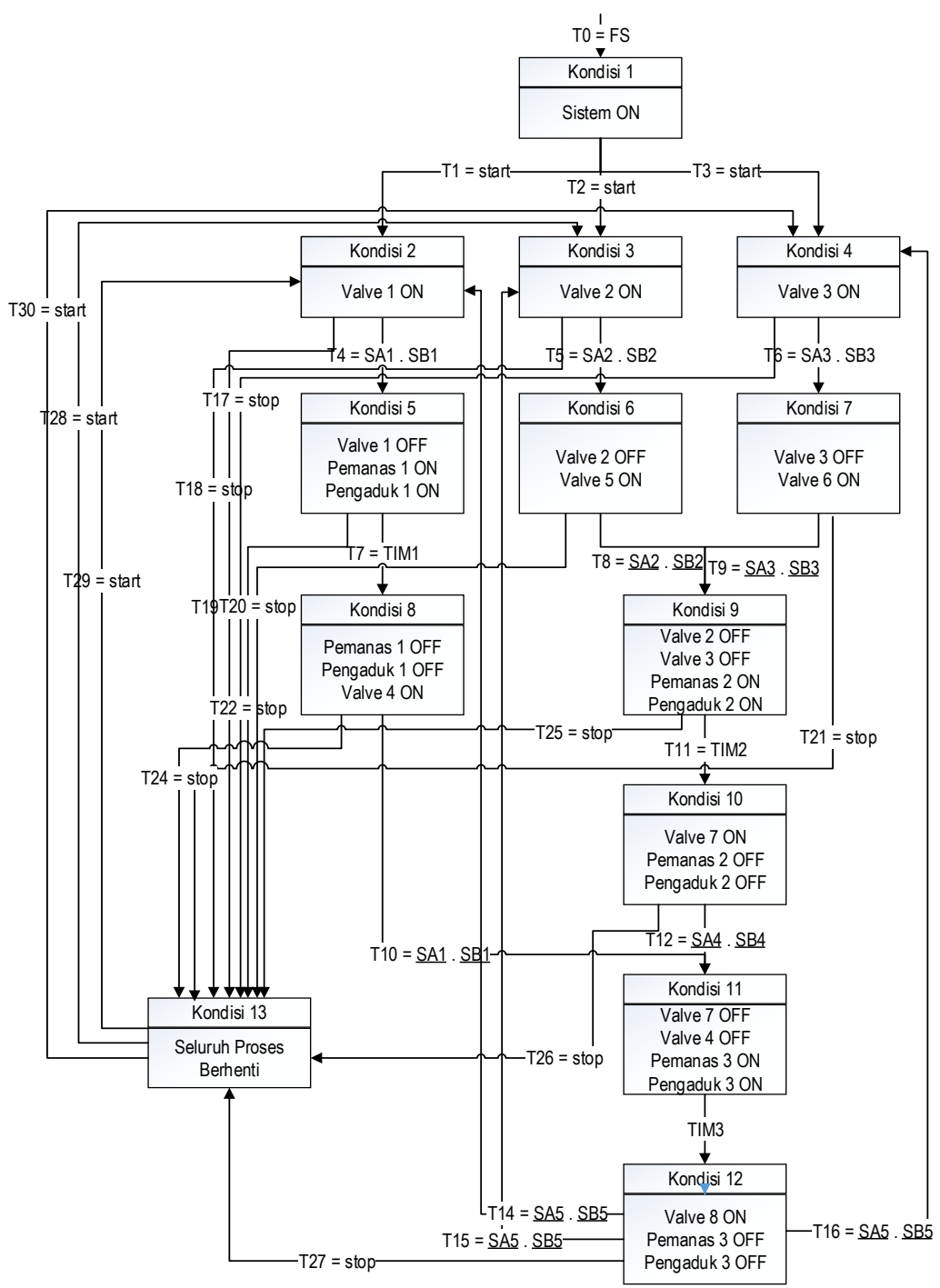

Gambar 6. Diagram keadaan sistem biodiesel 
Jurnal Ilmu Teknik Elektro Komputer dan Informatika (JITEKI)

Vol. 4, No.2, Desember 2018

Berdasarkan pada diagram keadaan didapatkan persamaan transisi (T0-T30) dan dikonversi ke bentuk diagram ladder pada Gambar 7.

\begin{tabular}{|c|c|}
\hline$T 0=$ Sistem $O N$ & T11 = TIM2. Kondisi 9 \\
\hline$T 1=$ Mulai. Kondisi 1 & $T 12=\overline{S A 4} \cdot \overline{S B 4}$. Kondisi 10 \\
\hline$T 2=$ Mulai. Kondisi 1 & $T 13=$ TIM3. Kondisi 11 \\
\hline T3 = Mulai. Kondisi 1 & $T 14=\overline{S A 5} . \overline{S B 5}$. Kondisi 12 \\
\hline$T 4=S A 1 . S B 1$. Kondisi 2 & $T 15=\overline{S A 5} . \overline{S B 5}$. Kondisi 12 \\
\hline$T 5=S A 2 . S B 2$. Kondisi 3 & $T 16=\overline{S A 5} \cdot \overline{S B 5}$. Kondisi 12 \\
\hline$T 6=S A 3 . S B 3$. Kondisi 4 & $T 17=$ Stop. Kondisi 4 \\
\hline$T 7=T I M 1$. Kondisi 5 & $T 18=$ Stop.. Kondisi 2 \\
\hline$T 8=\overline{S A 2} \cdot \overline{S B 2} \cdot$ Kondisi 6 & $T 19=$ Stop. Kondisi 3 \\
\hline$=\overline{S A 3} \cdot \overline{S B 3} \cdot$ Kondisi 7 & $T 20=$ Stop. Kondisi 6 \\
\hline 1. Kondisi 8 & $T 21=$ Stop. Kondisi 7 \\
\hline
\end{tabular}

T22 = Stop. Kondisi 5

T23 = Stop. Kondisi 9

T24 = Stop. Kondisi 8

T25 = Stop. Kondisi 10

T26 = Stop. Kondisi 11

T27 = Stop. Kondisi 12

T28 = Stop. Kondisi 13

T29 = Stop. Kondisi 13

T30 = Stop. Kondisi 13
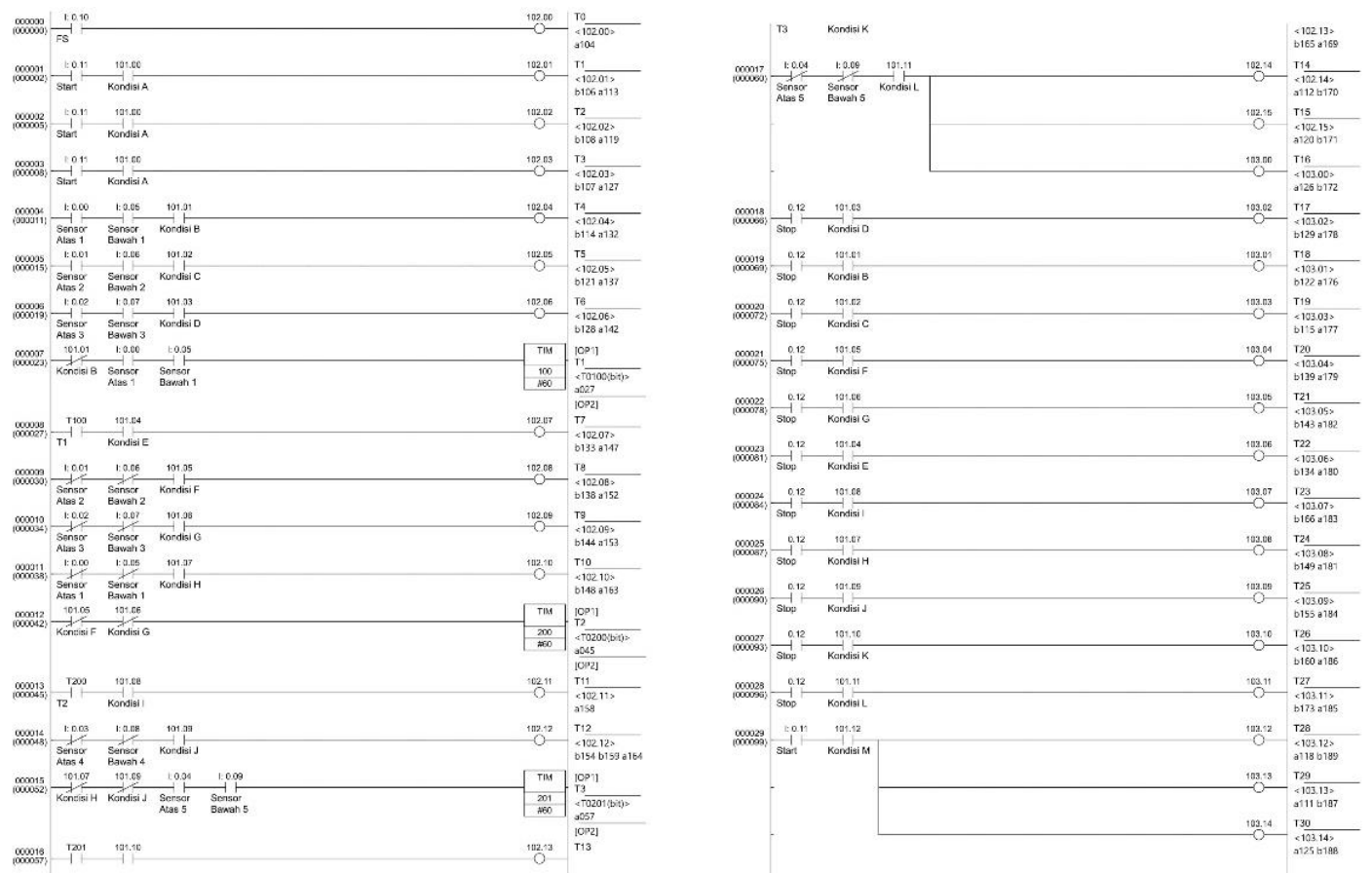

Gambar 7. Diagram ladder persamaan transisi

Berdasarkan pada persamaan transisi didapatkan persamaan keadaan (Kondisi 1-13) dan dikonversi ke bentuk diagram ladder pada Gambar 8.

Kondisi $1=($ Kondisi $1+T 0) . \overline{T 1} \cdot \overline{T 2} \cdot \overline{T 3}$

Kondisi $2=($ Kondisi $2+T 29+T 14+T 1) \cdot \overline{T 19} \cdot \overline{T 4}$

Kondisi $3=($ Kondisi $3+T 28+T 15+T 2) . \overline{T 5} \cdot \overline{T 18}$

Kondisi $4=($ Kondisi $4+T 30+T 16+T 3) \cdot \overline{T 6} \cdot \overline{T 17}$

Kondisi $5=($ Kondisi $5+T 4) \cdot \overline{T 7} \cdot \overline{T 22}$

Kondisi $6=($ Kondisi $6+T 5) \cdot \overline{T 8} \cdot \overline{T 20}$

Kondisi $7=($ Kondisi $7+T 6) \cdot \overline{T 9} \cdot \overline{T 21}$

Kondisi $8=($ Kondisi $8+T 7) \cdot \overline{T 10} \cdot \overline{T 24}$

Kondisi $9=($ Kondisi $9+T 8+T 9) \cdot \overline{T 11} \cdot \overline{T 23}$

Kondisi $10=($ Kondisi $10+T 11) \cdot \overline{T 12} \cdot \overline{T 25}$

Kondisi $11=($ Kondisi $11+T 10+T 12) \cdot \overline{T 23} \cdot \overline{T 13}$

Kondisi $12=($ Kondisi $12+T 13), \overline{T 14} \cdot \overline{T 15} \cdot \overline{T 27} \cdot \overline{T 16}$

Kondisi $13=($ Kondisi $13+T 17+T 18+T 19+T 20+T 21+T 22+T 23+T 24+T 25+T 26+T 27) \cdot \overline{T 28} \cdot \overline{T 29} \cdot \overline{T 30}$ 
Jurnal Ilmu Teknik Elektro Komputer dan Informatika (JITEKI)

Vol. 4, No.2, Desember 2018
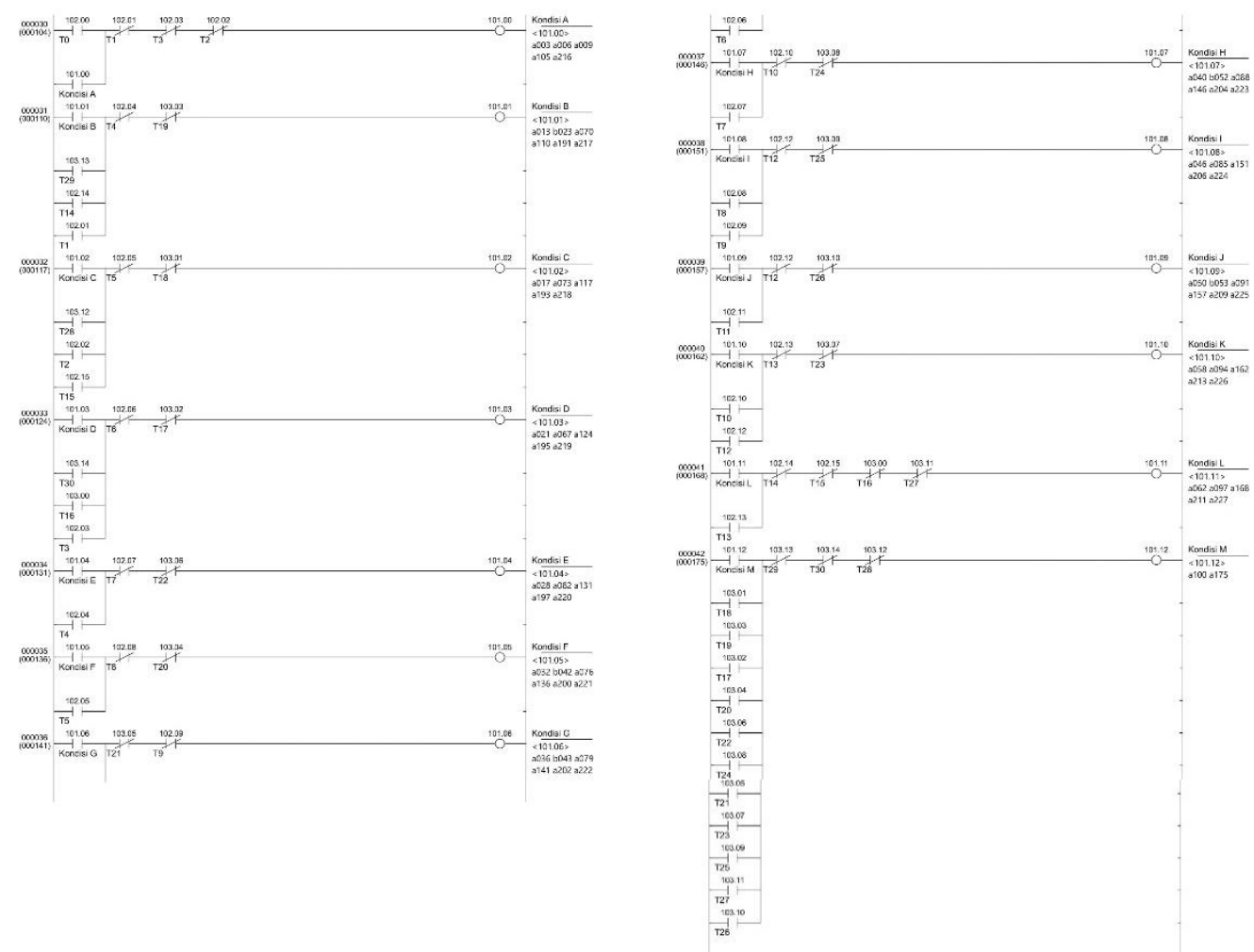

Gambar 8. Diagram ladder persamaan keadaan

Tabel 1 menunjukkan jenis keluaran yang ada pada sistem biodiesel berupa valve, pemanas, pengaduk dan lampu indikator sistem ketika menyala. Gambaran desain sistem biodiesel dapat dilihat pada Gambar 10 yang merupakan desain human machine interface (HMI). Desain HMI terdiri dari tampilan tombol dan lampu indikator sebagai gambaran keluaran sistem. Terdapat tiga tombol (Sistem ON, Mulai dan Berhenti) yang berfungsi untuk menyalakan sistem, menjalankan proses dan menghentikan proses. Indikator valve dan pemanas ditunjukkan dalam bentuk lampu yang terdiri dari 8 lampu untuk valve dan 3 lampu untuk pemanas. Lampu warna hijau berfungsi sebagai indikator pengaduk. Bentuk diagram ladder dari Tabel 1 ditunjukkan pada Gambar 9.

Tabel 1. Keluaran sistem biodiesel

\begin{tabular}{|c|c|c|c|c|c|c|c|c|c|c|c|c|c|}
\hline \multirow{2}{*}{$\begin{array}{c}\text { Jenis } \\
\text { Keluaran } \\
\end{array}$} & \multicolumn{13}{|c|}{ Kondisi } \\
\hline & 1 & 2 & 3 & 4 & 5 & 6 & 7 & 8 & 9 & 10 & 11 & 12 & 13 \\
\hline Valve1 & 0 & 1 & 0 & 0 & 0 & 0 & 0 & 0 & 0 & 0 & 0 & 0 & 0 \\
\hline Valve2 & 0 & 0 & 1 & 0 & 0 & 0 & 0 & 0 & 0 & 0 & 0 & 0 & 0 \\
\hline Valve3 & 0 & 0 & 0 & 1 & 0 & 0 & 0 & 0 & 0 & 0 & 0 & 0 & 0 \\
\hline Valve4 & 0 & 0 & 0 & 0 & 0 & 1 & 0 & 0 & 0 & 0 & 0 & 0 & 0 \\
\hline Valve5 & 0 & 0 & 0 & 0 & 0 & 0 & 1 & 0 & 0 & 0 & 0 & 0 & 0 \\
\hline Valve6 & 0 & 0 & 0 & 0 & 0 & 0 & 0 & 1 & 0 & 0 & 0 & 0 & 0 \\
\hline Valve7 & 0 & 0 & 0 & 0 & 0 & 0 & 0 & 0 & 0 & 1 & 0 & 0 & 0 \\
\hline Valve8 & 0 & 0 & 0 & 0 & 0 & 0 & 0 & 0 & 0 & 0 & 0 & 1 & 0 \\
\hline Pemanas 1 & 0 & 0 & 0 & 0 & 1 & 0 & 0 & 0 & 0 & 0 & 0 & 0 & 0 \\
\hline Pemanas 2 & 0 & 0 & 0 & 0 & 0 & 0 & 0 & 0 & 1 & 0 & 0 & 0 & 0 \\
\hline Pemanas 3 & 0 & 0 & 0 & 0 & 0 & 0 & 0 & 0 & 0 & 0 & 1 & 0 & 0 \\
\hline Pengaduk 1 & 0 & 0 & 0 & 0 & 1 & 0 & 0 & 0 & 0 & 0 & 0 & 0 & 0 \\
\hline Pengaduk 2 & 0 & 0 & 0 & 0 & 0 & 0 & 0 & 0 & 1 & 0 & 0 & 0 & 0 \\
\hline Pengaduk 3 & 0 & 0 & 0 & 0 & 0 & 0 & 0 & 0 & 0 & 0 & 1 & 0 & 0 \\
\hline Sistem ON & 1 & 1 & 1 & 1 & 1 & 1 & 1 & 1 & 1 & 1 & 1 & 1 & 0 \\
\hline
\end{tabular}


Jurnal IImu Teknik Elektro Komputer dan Informatika (JITEKI)

Vol. 4, No.2, Desember 2018

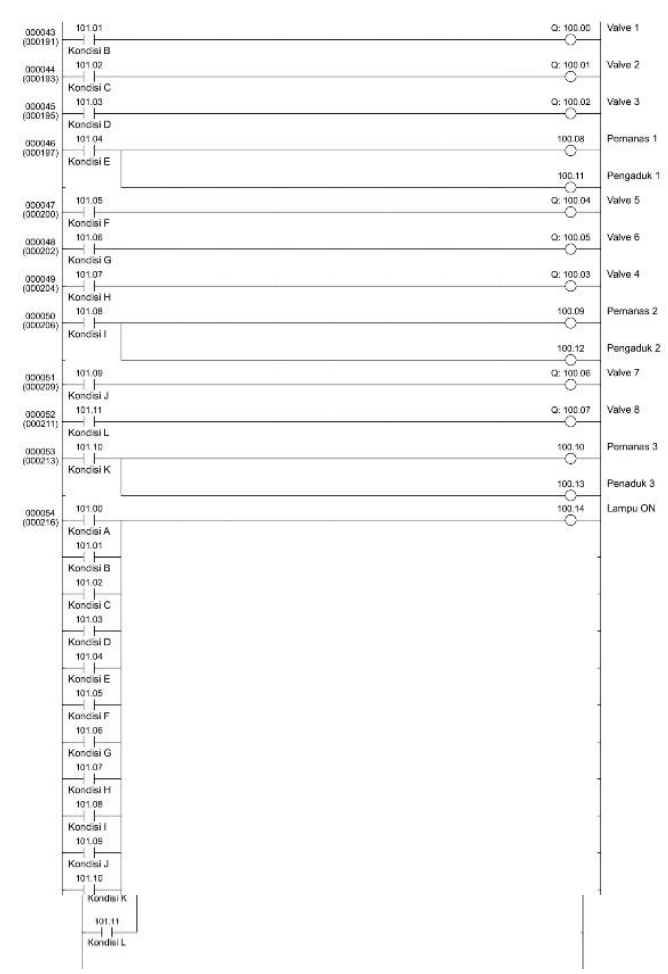

Gambar 9. Diagram ladder persamaan keluaran

Aplikasi metode konversi diagram keadaan ke diagram ladder pada sistem biodiesel yang dibuat dapat dilihat hasilnya dalam diagram pewaktuan (timing diagram). Gambar 10 menunjukkan diagram pewaktuan keluaran sistem yang diklasifikasikan pada masing-masing tangki. Berdasarkan Gambar 11 dapat disimpulkan bahwa perancangan pemrograman PLC untuk sistem biodiesel dari diagram keadaan ke diagram ladder berhasil dilakukan. Seluruh proses terbukti berhasil dilakukan. Perancangan diagram ladder dari diagram keadaan membutuhkan memori dari PLC.

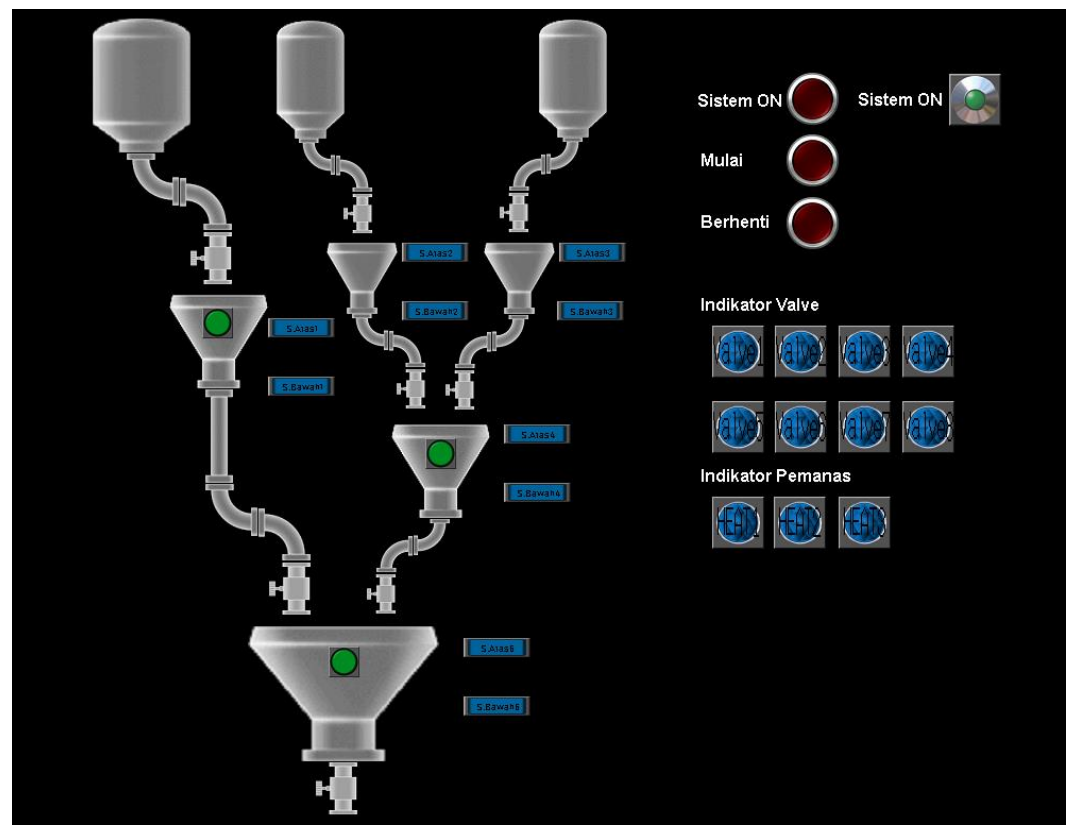

Gambar 10. Rancangan HMI sistem biodiesel 


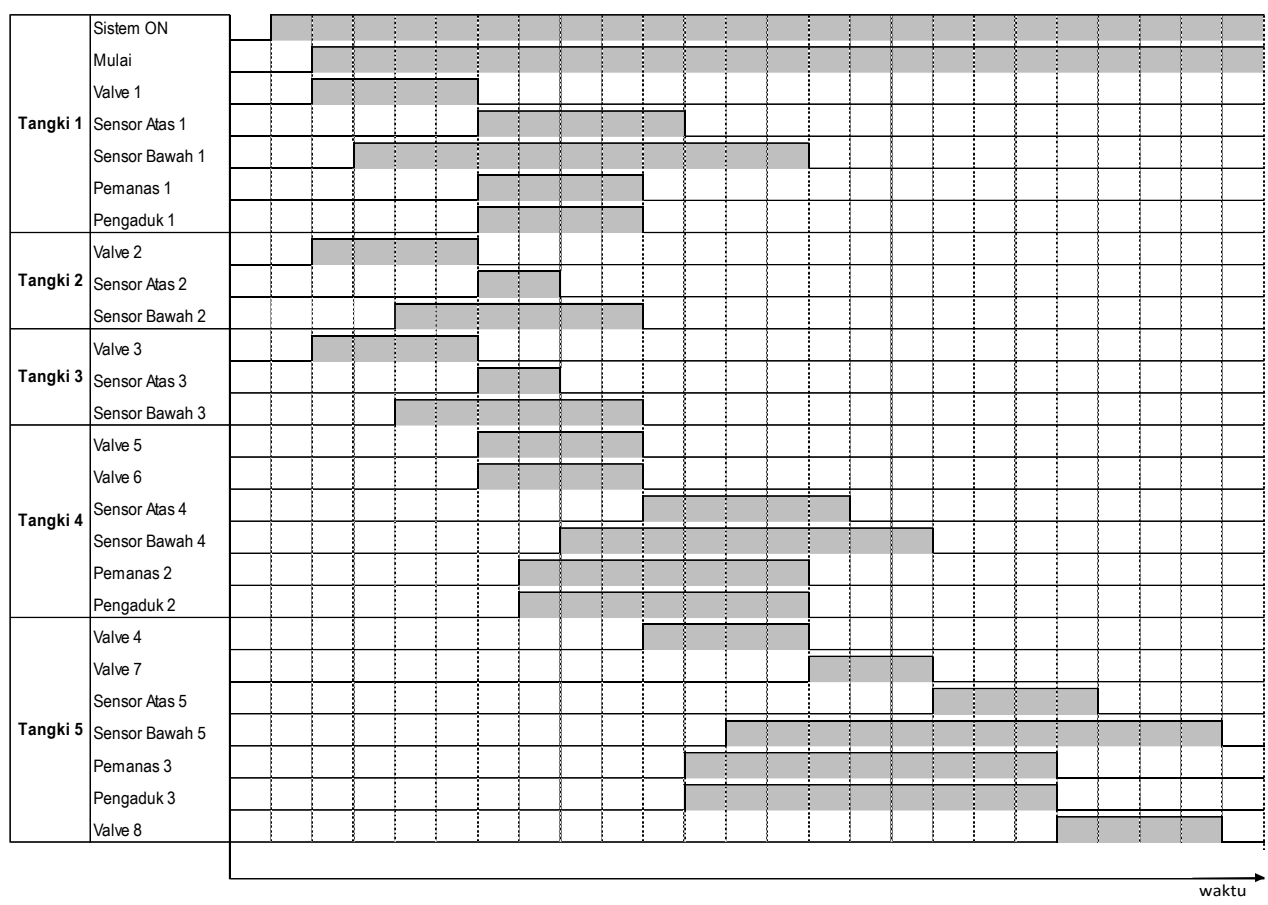

Gambar 11. Diagram pewaktuan

Pembuatan desain sistem biodiesel mengguna metode konversi dari diagram keadaan ke diagram ladder membutuhkan memori lebih banyak karena di dalamnya terdapat output transisi dan keadaan yang datanya harus disimpan untuk digunakan pada proses selanjutnya secara sekuensial. Tabel 2 menunjukkan memori yang digunakan dalam sistem biodiesel yang dirancang. Penggunan memori total sistem sebesar $6,5 \%$ dari total memori yang ada. Memori program merupakan memori yang digunakan PLC dalam menyimpan program. Memori symbol table merupakan memori yang digunakan untuk menyimpan simbol yang digunakan pada program PLC. Jumlah komentar dan keterangan yang dibuat oleh pembuat program ditunjukkan dengan memori annotation sedangkan memori program index digunakan untuk menunjukkan indeks

Tabel 2. Penggunaan memori (user memory)

\begin{tabular}{lc}
\hline \multicolumn{1}{c}{ Jenis Memori } & Jumlah step \\
\hline \hline Program & 322 step \\
\hline Symbol Table & 199 step \\
\hline Annotation & 33 step \\
\hline Program Index & 46 step \\
\hline Free UM & 8616 step \\
\hline Total (ukuran UM) & 9216 step \\
\hline
\end{tabular}

\section{Kesimpulan}

Sistem biodiesel merupakan salah satu jenis sistem yang berjalan secara berurutan (sekuensial) yang dapat diselesaikan dengan pengendali PLC. Perancangan sistem biodiesel dapat dilakukan dengan konversi diagram keadaan ke diagram ladder yang dilakukan secara terstruktur. Implementasi sistem ini pada PLC Omron CP1E membutuhkan memori sebesar 6,5\% dari total memori yang tersedia.

\section{Referensi}

[1] S. Wahyuni, Ramli, dan Mahrizal, "Pengaruh Suhu Proses dan Lama Pengendapan Terhadap Kualitas Biodiesel dari Minyak Jelantah", Pillar Phys., vol. 6, Oktober, hal. 33-40, 2015. 
[2] I. Aziz, S. Nurbayti, dan B. Ulum, "Pembuatan Produk Biodiesel Dari Minyak Goreng Bekas Dengan Cara Esterifikasi dan Transesterifikasi," Valensi, vol. 2, no. 3, hal. 443-448, 2011.

[3] D. Hidayat, T. A. Demen, A. Z. Ahmad and N. S. Syafei, "Otomasi Reaktor Transesterifikasi Biodiesel Berbasis Programmable Logic," Seminar Nasional Teknik Elektro, 2017.

[4] M. Budiyanto and A. Wijaya, "Pengenalan Dasar- Dasar PLC (Programmable Logic Controller) Disertai Contoh Aplikasinya", Yogyakarta: Gava Media, 2006.

[5] E. Iskandar, M. Rameli and N. , "Ladder Diagram based on State Diagram for Selection and Assembling Part on Dual Conveyor," Journal on Advanced Research in Electrical Engineering (JAREE), vol. 1, pp. 52-56, 2017.

[6] A. Verma, A. Sayyad, S. Kanherkar, H. Gore, H. Mahajan, S.D. Bankar and S. Namekar, "Control of Induction Motor Using PLC and VFD," International Research Journal of Engineering and Technology (IRJET), vol. 5, pp. 995-997, 2018.

[7] W. Bolton, "Programmable Logic Controllers", Newnes, 2015.

[8] G. Septiani, R. Tridesman and E. Ekawati, "Design and implementation of biodiesel washing automation system with set of sensors and programmable logic controller device," 2015 International Conference on Sustainable Energy Engineering and Application (ICSEEA), 2015.

[9] P. Fernandez, C. d. Carpio, E. Rocca and L. Vinces, "An Automatic Control System Using the S7-1200 Programmable Logic Controller for the Ethanol Rectification Process," 2018 IEEE XXV International Conference on Electronics, Electrical Engineering and Computing (INTERCON), 2018.

[10] I. Setiawan, "Programmable Logic Controller (PLC) dan Teknik Perancangan Sistem Kontrol", Yogyakarta: Andi, 2006. 